$\sqrt{3}$

J. bio-sci. 18: 134-139, 2010

ISSN 1023-8654

http://www.banglajol.info/index.php/JBS/index

\title{
SEDATION OF XYLAZINE AND LIGNOCAINE WITH ADRENALINE AND BUPIVACAINE FOR UMBILICAL SURGERY IN CALVES
}

\author{
NC Sarker*, MA Hashim, BP Ray, SK Sarker \\ Department of Surgery and Obstetrics, Bangladesh Agricultural University, Mymensingh 2002, Bangladesh
}

\begin{abstract}
Context: The use of sedatives in veterinary practice is indispensable as they help in overcoming resistance of the animal during examination, maintaining depth of anaesthesia, reducing the dose of anaesthetic agent and increasing the margin of safety. Thus, action of some sedatives and local analgesics in various regional anaesthesia in calves and their evaluation in respect of doses are of great significance. The approximation of dose rate of available sedatives in calves may be helpful for the practitioners.

Objectives: To determine the general effect of clinically useful dose of the sedatives produced by xylazine and lignocaine with adrenaline and bupivacaine for umbilical surgery in calves.

Materials and Methods: The experiment was performed on 20 affected with umbilical hernia, 6 were indigenous (local) and 14 were crossbred. They were divided into 4 groups and each group included 5 calves. Groupp A was sedated with xylazine hydrochloride and $2 \%$ lignocaine hydrochloride; Group B with xylazine hydrochloride followed by $0.5 \%$ bupivcaine hydrochloride; Group $C$ with diazepam followed by $2 \%$ lignocaine hydrochloride; and Group $D$ diazepam followed by $0.5 \%$ bupivacaine. Respiratory rate, heart rate and rectal temperature were recorded before administration of sedatives and at 15, 30, 45, 60 minutes after sedation and local analgesia.

Results: Heart rate and respiration rate significantly $(p<0.01)$ decreased during sedation with xylazine hydrochloride plus $2 \%$ lignocaine hydrochloride or $0.5 \%$ bupivacaine hydrochloride. A significantly decreased $(p<0.01)$ heart rate and respiration rate also found during sedation with diazepam plus $2 \%$ lignocaine hydrochloride or $0.5 \%$ bupivacaine hydrochloride. Duration of analgesia was longer with $0.5 \%$ bupivacaine hydrochloride $(55.88 \pm 1.58$ min in Group B and $48 \pm 11.25 \mathrm{~min}$ in Group D) compared to $2 \%$ lignocaine hydrochloride (39.60 \pm 5.77 min in Group A and $43.6 \pm$ $5.81 \mathrm{~min}$ in Group C). Xylazine hydrochloride showed short onset and long duration of sedation compared to diazepam.

Conclusion: For herniorraphy, xylazine hydrochloride can be used as a better sedative while $0.5 \%$ bupivacaine hydrochloride can be used as a local analgesic for longer duration of action.
\end{abstract}

Keywords: Xylazine, lignocaine, diazepam, sedation, analgesia.

\section{Introduction}

Diseases in calves are thought to be important constraints for cattle development in Bangladesh. It has been reported that $15-20 \%$ calves die per year from various diseases (Anon 1993). Congenital disorders in calves have been increasing alarmingly. Umbilical hernia, navel ill and atresia ani are among the major congenital disorders causing mortality in calves. Umbilical hernia is one of the major congenital affections in animal particularly in the bovine. The affected calves may only be treated through successful herniorraphy.

Clinical experience suggests that along with indigenous calves a considerable number of crossbred calves also suffer from various congenital abnormalities. So the surgical affections of calves may affect total performance of the dairy herds and above all the future generation and their health. New born calves frequently suffer from various surgical affections such as umbilical hernia, atresia ani, dermoid cyst, knuckling of the limbs, navel ill, umbilical abscesses. Das (1996) reported a high incidence (47.1\%) umbilical hernia among surgical affection in calves. This congenital defect may become dangerous if not treated in appropriate time. The affected calves may be only treated through successful herniorraphy. Many factors e.g. suture materials, suture pattern, degree of protrusion, body circumference, ring diameter etc. determine the success of herniorraphy (Peacock and Van Winkle 1976).

* Corresponding author : E-mail: ncsarker2010@gmail.com 
Sedatives are used for premedication which is an essential part of balanced anaesthetic regimen. This is necessary for both general and local anaesthesia (Hall and Clarke 1989). Local analgesia is considered to be very important in ruminant anaesthesia because general anaesthesia in ruminants very often lead to tympanities or regurgitation especially if anaesthesia is performed in unstarved condition (Hossain and Kumar 1988, Hashim 2004). Therefore herniorraphy in calves are performed under sedation and local analgesia or regional analgesia. Efficiency in operative procedure partly depends on efficient anaesthesia. The sedatives have been used in calves either alone or in combination with local, regional or general anaesthesia. The use of sedatives in veterinary practice is indispensable as they help in overcoming resistance of the animal during examination, maintaining depth of anaesthesia, reducing the dose of anaesthetic agent and increasing the margin of safety. Sedation of calves along with local anaesthetic is performed for the treatment of surgical interferences such as herniorraphy. Thus, action of some sedatives and local analgesics in various regional anaesthesia in calves and their evaluation in respect of doses are of great significance. The approximation of dose rate of available sedatives in calves may be helpful for the practitioners.

The commonly used local analgesic agents include lignocaine hydrochloride, lignocaine hydrochloride with adrenaline and bupivacaine hydrochloride. These local analgesic agents are used for local or regional analgesia. Lignocaine has a relatively rapid onset of action and intermediate duration of about 1 to 2 hours (Lumb and Jones 1996, Carpenter et al. 2004). Bupivacaine is a long acting local analgesic. It is about 4 times more potent than lignocaine and is used most commonly for regional nerve block (Eugene and Nicholas 1995). So, an experiment was carried out to determine the general effect of clinically useful dose of the sedatives in calves and study the action of various sedatives and local analgesics in calves.

\section{Materials and Methods}

Experimental Animal: The experimental work was carried out in the operation theatre of veterinary clinic, Bangladesh Agricultural University, Mymensingh, Gaibandha, Sirajgang and Kurigram Districts. The experiment was performed on 20 calves of ages ranging from 5 days to 4 months and body weights varied from 20 to $48 \mathrm{~kg}$. Out of 20 calves affected with umbilical hernia, 6 were indigenous (local) and 14 were crossbred. They were divided into 4 groups and each group included 5 calves. The calves were apparently healthy. The animals were starved of both food and water for 3 hours before sedation. An assistant restrained the animal physically and the drug was injected intramuscularly.

Use of Sedatives: Xylazine hydrochloride (Rompum $®)$, lignocaine hydrochloride (Jasocaine®), bupivacaine hydrochloride (Ultracaine®), and Diazepam (Seduxen $®)$; all from Jayson Pharmaceuticals Ltd. Bangladesh were used for the study. The experiments were done in four groups: Group A: Firstly xylazine hydrochloride was injected at a dose rate of $0.1 \mathrm{mg} \mathrm{kg}^{-1}$ body weight intramuscularly. Ten minute later $2 \%$ lignocaine hydrochloride was injected at a dose rate of $10 \mathrm{ml}$ and then required dose for local infiltration. Group B: The animals were sedated using xylazine hydrochloride @ $0.11 \mathrm{mg} \mathrm{kg}^{-1}$ intramuscularly and were local analgesized using $0.5 \%$ bupivcaine hydrochloride ten minute later for local infiltration. Group C: At first diazepam was injected at a dose rate of $0.5 \mathrm{mg} \mathrm{kg}^{-1}$ body weight intramuscularly. Twenty to thirty minute later $2 \%$ lignocaine hydrochloride was injected at a dose rate of $10 \mathrm{ml}$ and then required dose for local infiltration. Group D: Twenty to thirty minute prior to analgesia diazepam was injected at a dose rate of 0.5 $\mathrm{mg} \mathrm{kg}^{-1}$ body weight intramuscularly, $0.5 \%$ bupivacaine hydrochloride was injected at a dose rate of $10 \mathrm{ml}$ and then required dose for local infiltration

Observation in animals: Immediately after injection of drugs the animals were observed for various behavioural changes i.e. changes in attitude, outlook, and posture and time parameters like onset time, down time and recovery time. The depth of sedation and local analgesia were assessed by monitoring various 
ocular reflexes, pain prick reflexes, relaxation of neck, jaws, salivation, lacrimation, urination and granting, respiration rate, heart rate and rectal temperature were observed.

Statistical Analysis: Student's paired "t" test was performed to compare the obtained before anaesthesia and 15, 30, 45 and 60 min. after anaesthesia. Analysis of variance (ANOVA test) in completely randomized design was carried out to test significance of variation among the effects in different time interval.

\section{Results}

General Signs after Administration of Sedatives in Calves: Drooping of the upper eyelids, droopy head, salivation and lateral recumbency were observed in all the calves after onset of sedation with xylazine hydrochloride at the dose rate of $0.13 \pm 01 \mathrm{mg} \mathrm{kg}^{-1}$ and $0.12 \pm 0.01 \mathrm{mg} \mathrm{kg}^{-1}$ in Groups $A$ and B respectively. There was milk fever like recumbency and muscle relaxation was observed. The calf of Group $A$ and Group B showed severe drowsiness $8.0 \pm 0.71$ and $7.0 \pm 0.71 \mathrm{~min}$ after administration of xylazine hydrochloride respectively.

Diazepam at the dose rate of $1.02 \pm 0.05 \mathrm{mg} \mathrm{kg}^{-1}$ and $1.06 \pm 0.04 \mathrm{mg} \mathrm{kg}^{-1}$ in Group C and Group D respectively produced drowsiness, walking in circle, drooping of the upper eyelids and droopy head in all the calves. Sleepy impression, lateral deviation of the head and relaxation of the muscle were also observed. Six calves out of 10 of Group C and Group D were found to have good sedation. Onset of sedation was 20.20 \pm 1.50 min in Group C and $21.40 \pm 1.29$ min in Group D respectively.

Effects of Various Sedative and Analgesic Drugs on Clinical Parameters: Effects of various sedative and analgesic drugs on heart rates, respiration rates and rectal temperature in calf are presented in Table 1. Before sedation, the mean values of heart rates, respiration rates and rectal temperature were $83.40 \pm 3.60 \mathrm{~min}^{-1}$, $28 \pm 1.30 \mathrm{~min}^{-1}$ and $101.80 \pm 0.22^{\circ} \mathrm{F}$, respectively in Group A. These mean values $15 \mathrm{~min}$ after sedation were $73.40 \pm 2.66 \mathrm{~min}^{-1}, 22 \pm 1.46 \mathrm{~min}^{-1}$ and $101.60 \pm 0.21^{\circ} \mathrm{F}$ respectively. Heart rates and respiration rates were decreased significantly $(P<0.01)$ after $15 \mathrm{~min}$ and also $30 \mathrm{~min}$ of sedation. But rectal temperature was not decreased significantly. Heart rates were significantly $(P<0.01)$ decreased 45 and 60 min after sedation as compared to pre sedative values. In Group B, the mean values of heart rates, respiration rates and rectal temperature were $80.20 \pm 3.69 \mathrm{~min}^{-1}, 25.80 \pm 1.93 \mathrm{~min}^{-1}$ and $101.82 \pm 0.22^{\circ} \mathrm{F}$, respectively. These mean values $15 \mathrm{~min}$ after sedation were $71.20 \pm 3.68 \mathrm{~min}^{-1}, 21.60 \pm 1.29 \mathrm{~min}^{-1}$ and $101.58 \pm 0.21^{\circ} \mathrm{F}$, respectively. The heart rates and respiration rates were significantly $(P<0.01)$ reduced after $15 \mathrm{~min}$ and $30 \mathrm{~min}$ of sedation. Heart rates and respiration rates were significantly $(P<0.01)$ decreased $45 \mathrm{~min}$ and $60 \mathrm{~min}$ of sedation as compared to pre sedative values. But rectal temperature was not decreased significantly.

In Group C, the mean values of heart rates, respiration rates and rectal temperature were $80.00 \pm 4.73 \mathrm{~min}^{-1}$, $80.00 \pm 4.73 \mathrm{~min}^{-1}$ and $101.50 \pm 0.25^{\circ} \mathrm{F}$ respectively before sedation. During $15 \mathrm{~min}$ of sedation, heart rates, respiration rates and rectal temperature were $73.60 \pm 3.85 \mathrm{~min}^{-1}, 23.60 \pm 1.33 \mathrm{~min}^{-1}$ and $101.40 \pm 0.25^{\circ} \mathrm{F}$ per min. respectively and they decreased significantly $(P<0.01)$ as compared to pre sedative values. Heart rates and respiration rates were significantly $(P<0.01)$ reduced during $15 \mathrm{~min}$ and $30 \mathrm{~min}$ after sedation. In Group D, the mean values of heart rates, respiration rates, and rectal temperature were $74.40 \pm 2.32 \mathrm{~min}^{-1}$, $24.60 \pm 2.38 \mathrm{~min}^{-1}$ and $101.70 \pm 0.20^{\circ} \mathrm{F}$ respectively before anaesthesia. Fifteen min after sedation heart rates and respiration rates and rectal temperature were not significantly decreased compared to preanaesthetic values.

The Onset and duration of Sedation: The mean values of onset of sedation are presented in Table 2. The onset of sedation occurred within 6-10 minutes in all animals of Group A and the mean values of onset was $8.00 \pm 1.58 \mathrm{~min}$. In Group B, the mean value of onset was $7.00 \pm 1.58 \mathrm{~min}$ and onset occurred within 7-9 min. In Group C, the onset of sedation occurred within 16-24 min and the mean value of onset was $20.20 \pm 3.35$ 
min. The mean value of onset was $21.40 \pm 2.88 \mathrm{~min}$ in Group D. Onset of occurred within 18-25 min in all animals of Group D. The variations between different groups in term of onset and duration of sedation were insignificant.

The Onset and duration of Analgesia: The mean values of onset of analgesia are presented in Table 3. The onset of analgesia occurred within 4-8 minutes in all animals of Group $A$ and the mean values of onset was $5.60 \pm 1.52 \mathrm{~min}$. In Group B, the mean value of onset was $8.00 \pm 1.58 \mathrm{~min}$ and onset occurred within 6-10 min. In Group C, the onset of analgesia occurred within 2-5 min and the mean value of onset was $3.00 \pm$ $1.22 \mathrm{~min}$. The mean value of onset was $7.80 \pm 1.30 \mathrm{~min}$ in Group D and occurred within 6-9 min.

Xylazine hydrochloride produced rapid onset and a longer duration of sedation compared to diazepam and xylazine hydrochloride significantly decreased respiration rates and heart rates compared to diazepam. $2 \%$ lignocaine hydrochloride produces rapid onset of analgesia compared to $0.5 \%$ bupivacaine hydrochloride and $0.5 \%$ bupivacaine hydrochloride produces prolong duration of analgesia compared to $2 \%$ lignocaine hydrochloride.

Table 1. Effects of sedative and analgesic agent on heart rate $\left(\mathrm{min}^{-1}\right)$, respiration rate $\left(\mathrm{min}^{-1}\right)$ and rectal temperature $\left({ }^{\circ} \mathrm{F}\right)$ of calves

\begin{tabular}{|c|c|c|c|c|c|c|}
\hline \multirow[b]{2}{*}{$\begin{array}{l}\text { Clinical } \\
\text { parameter }\end{array}$} & \multirow[b]{2}{*}{ Group } & \multicolumn{5}{|c|}{ sedation } \\
\hline & & Before & After $15 \mathrm{~min}$ & $\begin{array}{l}30 \text { minutes after } \\
\text { sedation }\end{array}$ & $\begin{array}{c}45 \text { minutes after } \\
\text { sedation }\end{array}$ & $\begin{array}{l}60 \text { minutes after } \\
\text { sedation }\end{array}$ \\
\hline \multirow{4}{*}{ Heart rate } & $A$ & $83.40 \pm 3.60$ & $73.40 \pm 2.66^{\star *}$ & $68.40 \pm 2.42^{\star *}$ & $67.00 \pm 2.77^{\star \star}$ & $67.80 \pm 3.07^{\star \star}$ \\
\hline & $B$ & $80.20 \pm 3.60$ & $71.20 \pm 3.68^{* *}$ & $66.00 \pm 2.85^{\star *}$ & $61.20 \pm 2.48^{* *}$ & $60.20 \pm 3.22^{\star *}$ \\
\hline & C & $80.00 \pm 4.73$ & $73.60 \pm 3.85^{\star *}$ & $70.80 \pm 4.12^{* *}$ & $72.20 \pm 3.46^{*}$ & $70.80 \pm 3.22^{\star *}$ \\
\hline & $D$ & $74.40 \pm 0.23$ & $71.40 \pm 0.60^{\mathrm{ns}}$ & $69.60 \pm 2.80^{\mathrm{ns}}$ & $67.60 \pm 3.59^{\mathrm{ns}}$ & $67.60 \pm 3.78^{\mathrm{ns}}$ \\
\hline \multirow{4}{*}{$\begin{array}{l}\text { Respiration } \\
\text { rate }\end{array}$} & $A$ & $28.00 \pm 1.30$ & $22.00 \pm 1.46^{\star *}$ & $20.00 \pm 1.67^{\star *}$ & $19.40 \pm 1.54^{\star *}$ & $20.40 \pm 1.12^{\star \star}$ \\
\hline & $B$ & $25.80 \pm 1.93$ & $21.60 \pm 1.29^{* *}$ & $18.00 \pm 1.05^{\star *}$ & $16.60 \pm 0.93^{* *}$ & $16.80 \pm 1.53^{* *}$ \\
\hline & C & $26.60 \pm 1.29$ & $23.60 \pm 1.33^{* *}$ & $24.80 \pm 2.27^{* *}$ & $22.60 \pm 2.01^{\mathrm{ns}}$ & $23.80 \pm 1.69 \mathrm{~ns}$ \\
\hline & $D$ & $24.60 \pm 2.38$ & $21.80 \pm 2.08^{n s}$ & $20.00 \pm 1.70^{n s}$ & $18.20 \pm 2.20^{\mathrm{ns}}$ & $19.60 \pm 2.77^{\mathrm{ns}}$ \\
\hline \multirow{4}{*}{$\begin{array}{l}\text { Rectal } \\
\text { temperature }\end{array}$} & $A$ & $101.80 \pm 0.22$ & $101.60 \pm 0.21$ & $101.26 \pm 0.20$ & $101.06 \pm 0.19$ & $100.96 \pm 0.14$ \\
\hline & $B$ & $101.82 \pm 0.22$ & $101.58 \pm 0.21$ & $101.36 \pm 0.21$ & $101.10 \pm 0.16$ & $100.90 \pm 0.15$ \\
\hline & C & $101.50 \pm 0.25$ & $101.40 \pm 0.25$ & $101.14 \pm 0.21$ & $101.22 \pm 0.26$ & $100.70 \pm 0.15$ \\
\hline & D & $101.70 \pm 0.20$ & $101.46 \pm 0.22$ & $101.28 \pm 0.22$ & $101.06 \pm 0.17$ & $100.90 \pm 0.17$ \\
\hline \multicolumn{7}{|c|}{${ }^{*}$ Significant $(P<0.05){ }^{* *}$ Significant $(P<0.01) \quad$ ns-nonsignificant $(P>0.05)$} \\
\hline Group & $\begin{array}{c}\text { nitial dose rate } \\
\mathrm{mg} \mathrm{kg}^{-1} \mathrm{BW}\end{array}$ & $\begin{array}{l}\text { Time of onset of } \\
\text { sedation (min) }\end{array}$ & $\begin{array}{c}\text { Duration of } \\
\text { sedation (min) }\end{array}$ & $\begin{array}{c}\text { Further dose } \\
\mathrm{mg} \mathrm{kg}^{-1}\end{array}$ & $\begin{array}{l}\text { Extra duration of } \\
\text { sedation (min) }\end{array}$ & $\begin{array}{l}\text { Duration of deep } \\
\text { sedation (min) }\end{array}$ \\
\hline$A$ & $0.13 \pm 0.01$ & $8.00 \pm 1.58$ & $60.00 \pm 4.42$ & - & - & $22.60 \pm 5.32$ \\
\hline B & $0.12 \pm 0.01$ & $7.00 \pm 1.58$ & $60.00 \pm 2.00$ & - & - & $15.80 \pm 5.26$ \\
\hline C & $1.02 \pm 0.11$ & $20.20 \pm 3.35$ & $39.60 \pm 3.78$ & $0.44 \pm 0.11$ & $21.80 \pm 4.43$ & - \\
\hline $\mathrm{D}$ & $1.06 \pm 0.10$ & $21.40 \pm 2.88$ & $41.06 \pm 3.84$ & $0.44 \pm 0.11$ & $21.00 \pm 5.34$ & - \\
\hline
\end{tabular}

Table 3. Effect of analgesic on herniorraphy in calf sedated with sedative and local infiltration form

\begin{tabular}{clccccc}
\hline Group & $\begin{array}{c}\text { Form of local } \\
\text { infiltration }\end{array}$ & $\begin{array}{c}\text { Initial dose } \\
(\mathrm{ml})\end{array}$ & $\begin{array}{c}\text { Time of onset of } \\
\text { analgesia }(\mathrm{min})\end{array}$ & $\begin{array}{c}\text { Duration of } \\
\text { analgesia ( min) }\end{array}$ & $\begin{array}{c}\text { Further dose } \\
(\mathrm{ml})\end{array}$ & $\begin{array}{c}\text { Extra duration of } \\
\text { analgesia ( } \mathrm{min})\end{array}$ \\
\hline $\mathrm{A}$ & $\begin{array}{l}\text { Inverted "V" from } \\
\text { anterior side }\end{array}$ & 10.00 & $5.60 \pm 1.52$ & $39.60 \pm 5.77$ & $4.40 \pm 1.14$ & $22.40 \pm 4.33$ \\
$\mathrm{~B}$ & $\begin{array}{l}\text { Inverted "U" from } \\
\text { anterior side }\end{array}$ & 10.00 & $8.00 \pm 1.58$ & $55.80 \pm 1.58$ & $0.60 \pm 1.34$ & $3.20 \pm 7.15$ \\
$\mathrm{C}$ & Ring shape & 10.00 & $3.00 \pm 1.22$ & $43.60 \pm 5.81$ & $2.60 \pm 1.14$ & $15.20 \pm 8.35$ \\
$\mathrm{D}$ & $\begin{array}{l}\text { Inverted "L" from } \\
\text { both side }\end{array}$ & 10.00 & $7.80 \pm 1.30$ & $48.00 \pm 11.25$ & $2.40 \pm 1.94$ & $14.00 \pm 10.30$ \\
\hline
\end{tabular}




\section{Discussion}

Xylazine, one of the alpha 2 agonists, has been widely used in veterinary practice both systemically as a sedative and analgesic drug (Thurman et al. 1989), and neuraxially for analgesia in various species (Caron and LeBlanc 1989, DeRossi et al. 2003, Grubb et al. 1993, LeBlanc et al. 1988, St. Jean et al. 1990). It causes muscle relaxation and, depending on the dose used, it can induce cardiorespiratory depression, a fall in body temperature, a reduction in ruminal activity, a reduction in swallowing (hence, drooling of saliva) with an increased risk of aspiraton, and diuresis (Picavet et al. 2004, Thurman et al. 1989, Zuagg and Nussbaum 1990). Kamiloglu et al. (2005) indicated that epidural administration of xylazine-lidocaine combination following sedation with xylazine provided satisfactory analgesia for perineal and lower urinary tract surgery without any complications. However, as observed by Lewis et al. (1999), satisfactory analgesia for umbilical surgery was not achieved. It is suggested that $2 \%$ lignocaine hydrochloride is suitable for minor surgery but $0.5 \%$ bupivacaine hydrochloride may be used if a longer time of analgesia is required for surgery. However, lignocaine plus adrenaline should be avoided in case of cardiac insufficiency (Sarker et al. 2009).

Administration of xylazine along with ketamine resulted in more rapid onset and longer duration of analgesia $(P<0.05)$, without any measurable cardiopulmonary side effects (Saifzadeh et al. 2007, Sarrafzadeh-Rezaei et al. 2007). In caudal epidural analgesia, $0.5 \%$ bupivacaine hydrochloride and lignocaine hydrochloride (2\%) significantly decreased heart rates. This finding is in agreement with the earlier studies (Kinjavdekar and Pratap 2002). When $2 \%$ lignocaine hydrochloride was used, respiration rates decreased insignificantly. This observation corresponds with the study of the earlier investigators (Hossain and Kumar 1988). In this study, rectal temperature in calves of all groups decreased. Since, the spinal nerve always carries sympathetic fibre, peripheral nerve block always produces vasodilatation (Hall and Clarke 1989). There is usually fall in body temperature due to peripheral vasodilatation in the area of blockade.

In $2 \%$ lignocaine with adrenaline analgesia, the mean values of heart rate, respiration rate and rectal temperature before anaesthesia were $74.0 \pm 8.3 \mathrm{~min}^{-1}, 32.6 \pm 11.6 \mathrm{~min}^{-1}, 103.2 \pm 0.7^{\circ} \mathrm{C}$ respectively. Heart rate and respiration rates were significantly $(p<0.01)$ increased during $5 \mathrm{~min}$ after analgesia as compared to preanalgesic values but temperature decreased insignificantly (Table 1). This observation corresponds with the study of Luna et al. (2004). Generally, adrenaline in local analgesic solution causes peripheral vasoconstriction. Several compensating physiological mechanisms are activated when a partial sympathetic

blockade occurs. There is an increase in heart rate as a compensating mechanism to maintain cardiac output and blood pressure (Soma 1971). Adrenaline increases heart and respiration rates by activating $a$ and $\beta$ receptors (Brander et al. 1991).

Howel et al. (1990) observed that the onset of analgesia was slow with $0.5 \%$ bupivacine hydrochloride and the onset was more rapid with $2 \%$ lignocaine hydrochloride, while Trim (1989) stated that lignocaine hydrochloride with adrenaline had a more rapid onset than bupivacaine hydrochloride. The protein binding characteristics of local analgesic agents influence the duration of action (Hall and Clarke 1989). The duration of analgesia with $0.5 \%$ bupivacaine hydrochloride was significantly longer than $2 \%$ lignocaine hydrochloride. This observation supports the previous findings (Grubb et al. 1992).

\section{Conclusions}

For herniorraphy, xylazine hydrochloride can be used as a better sedative while $0.5 \%$ bupivacaine hydrochloride can be used as a local analgesic for longer duration of action.

\section{References}

Anon. 1993. Economic review. Livestock Subsector, Directorate of livestock services, Bangladesh.

Brander GC, Pugh DM, Bywater RJ, Jenkins WL. 1991. Veterinary Applied Pharmacology and Therapeutics. $5^{\text {th }}$ edn, ISBN, Bailliere Tindall, London. 
Caron JP, LeBlanc PH. 1989. Caudal epidural analgesia in cattle using xylazine. Can J Vet Res 53, 486-489. PMid:2590877 PMCid:1255581

Carpenter RE, Wilson DV, Evans AT. 2004. Evaluation of intraperitoneal and incisional lidocaine or bupivacaine or analgesia following ovarihysterectomy in the dog. Anaes Analg 31, 46-52. http://dx.doi.org/10.1111/j.1467-2995.2004.00137.x PMid:14756753

Das BR and Hashim, MA. 1996. Studies on surgical diseases in calves. Bangladesh Vet J 30, 53-57.

DeRossi R, Junqueira AL, Beretta MP. 2003. Analgesic and systemic effects of ketamine, xylazine and lidocaine after subarachnoid administration in goats. Am J Vet Res 64, 51-56. http://dx.doi.org/10.2460/ajvr.2003.64.51 PMid:12518878

Eugene PS, Nicholas HB. 1995. Local Anaesthetics. In: Veterinary Pharmacology and Therapeutics. State University Press. pp. 271358.

Grubb TL, Riebold TW, Huber MJ. 1992. Comparison of lidocaine, xylazine/lidocaine for caudal epidural analgesia in horses. J Am Vet Med Assoc 201, 1187-1190. PMid:1429156

Grubb TL, Riebold TW, Huber MJ. 1993. Evaluation of lidocaine, xylazine and a combination of lidocaine and xylazine for epidural analgesia in llamas. J Am Vet Med Asso 203, 1441-1444. PMid:8276706

Hall LW, Clarke KW. 1989. Veterinary Anaesthesia. 10 th edn. Toronto, Ont.: Bailler Taindall, London. pp.75-364.

Hasihm MA. 2004. The effect of local analgesics for postoperative pain control after overiohysterectomy in the dog and cat. A project report, Department of Clinical Veterinary Science, University of Bristol, Langford House, Langford. Bristol BS 40 5DU, Uk. pp. 1-8.

Hossain SS, Kumar A. 1988. Evaluation of lignocaine with and without amylalcohol as along acting epidural analgesia in buffaloes. Indian J Anim Sci 58, 1033-1036.

Howell P, Davies WM, Wrigley P, Morgan B. 1990. Comparison of four local extradural anaesthetic solution for effective caesarean section. Brit J Anaesth 65, 648-653. http://dx.doi.org/10.1093/bja/65.5.648 PMid:2248843

Kamiloglu A, Kamiloglu NN, Ozturk S, Atalan G, KIlıc E. 2005. Clinical assessment of epidural analgesia induced by xylazine-lidocaine combination accompanied by xylazine sedation in calves. Irish Vet J 58, 567-570. http://dx.doi.org/10.1186/2046-0481-58-10-567 PMCid:3113916

Kinjavdekar P, Pratap K. 2002. Comparison of ketamine and xylazine for lumbo-sacral epidural ajalgesia in buffalo calves. Indian J Vet Surg 21, 117.

LeBlanc PH, Caron JP, Patterson JS, Brown M, Matta MA. 1988. Epidural injection of xylazine for perineal analgesia in horses. J Am Vet Med Asso 193, 1405-1408. PMid:3209451

Lewis CA, Constable PD, Huhn JC, Morin DE. 1999. Sedation with xylazine and lumbosacral epidural administration of lidocaine and xylazine for umbilical surgery in calves. J Am Vet Med Asso 214, 89-95. PMid:9887947

Lumb WV and Jones EW. 1996. Veterinary Anaesthesia. 1st edn. Lea and Febiger, Philadelphia. pp. 179-208.

Luna SP, Cassu RN, Castro GB, Teixeira NFJ, Junior JR, Lopes MD. 2004. Effects of four anaesthetic protocols on the neurological and cardiorespiratory variables of puppies born by caesarean section. Vet Rec 154(13), 387-389. http://dx.doi.org/10.1136/ vr.154.13.387 PMid:15083971

Peacock EEJ, Van Winkle W. 1976. Wound repair. Surg Gynecol Obst 140, 7-10.

Picavet MT, Gasthuys FM, Laevens HH, Watts SA. 2004. Cardiopulmonary effects of combined xylazine-guaiphenesin-ketamine infusion and extradural (inter-coccygeal I idocaine) anaesthesia in calves. Vet Anaes Analg 31, 11-19. http://dx.doi.org/10.1046/ j.1467-2987.2003.00127.x PMid:14756749

Saifzadeh S, Pourjafar M, Naghadeh BD. 2007. Caudal Extradural Analgesia with Lidocaine, Xylazine, and a Combination of Lidocaine and Xylazine in the Iranian River Buffalo (Bubalus bubalis). Irian J Vet Surg 2(3), 7-13

Sarker K, Hashim MA, Hossain MA, Lucky NS. 2009. Caudal epidural analgesia in calves using different local analgesics. J Bangladesh Agril Univ 7(1), 53-56

Sarrafzadeh-Rezaei F, Rezazadeh F, Behfar M. 2007. Comparison of Caudal Epidural Administration of Lidocaine and Xylazine to Xylazine/Ketamine Combination in Donkey (Equus asinus). Irian J Vet Surg 2(5), 7-15

Soma LR. 1971. Text book of Veterinary Anaesthesia. The Williams and Wilkins Company Baltimore, USA, pp. 450-467.

St. Jean G, Skarda RT, Muir WW, Hoffsis GF. 1990. Caudal epidural analgesia induced by xylazine administration in cows. Am J Vet Res 51, 1232-1236. PMid:2386320

Thurman JC, Lin HG, Tranquilli WJ. 1989. A comparison of yohimbine and talazoline as antagonists of xylazine sedation in calves. Vet Surg 18, 170-171.

Trim CM. 1989. Epidural analgesia with $0.75 \%$ Bupivacaine for laparotomy in goats. J Am Vet Med Assoc 194(9), 1292-1296. PMid:2722662

Zaugg JL, Nussbaum M. 1990. Epidural injection of xylazine: a new option for surgical analgesia of the bovine abdomen and udder. Vet Med 85, 1043-1046. 